\title{
PEMANFAATAN LIMBAH PADAT PERTANIAN DAN PERIKANAN SEBAGAI BIOSORBEN UNTUK PENYERAP BERBAGAI ZAT WARNA: SUATU TINJAUAN
}

\section{UTILIZATION OF AGRICULTURAL BY-PRODUCTS AND FISHERY SOLID WASTE AS BIOSORBENTS FOR VARIOUS DYES: A REVIEW}

\author{
Putri Ramadhani ${ }^{1}$, Rahmiana Zein ${ }^{1, *}$, Zulkarnain Chaidir $^{1}$, Zilfa $^{1}$, Linda Hevira ${ }^{2}$ \\ ${ }^{1}$ Jurusan Kimia FMIPA Universitas Andalas \\ Limau Manis, Pauh, Kota Padang, Sumatera Barat, Indonesia, 25163 \\ ${ }^{2}$ Universitas Mohammad Natsir. Jl. Tan Malaka Bukit Cangang. Bukittinggi. \\ Sumatera Barat, 26138 \\ *e-mail korespondensi: rzein@ sci.unand.ac.id
}

\begin{abstract}
Abstrak
Artikel ulasan ini memaparkan perkembangan terkini pada aplikasi metode adsorpsi dalam menghilangkan zat warna dalam air limbah. Artikel ulasan ini memberikan informasi mengenai aplikasi zat warna serta penanganan limbah dari aktivitas industri yang menggunakan zat warna dan informasi mengenai penggunaan limbah padat pertanian dan perikanan sebagai penyerap berbagai jenis zat warna. Pengolahan limbah yang mengandung zat warna melalui adsorpsi menggunakan adsorben alternatif berbiaya rendah merupakan bidang yang saat ini berkembang dan banyak diminati karena memiliki manfaat yaitu untuk pengelolaan limbah cair dan pemanfaatan limbah padat organik.
\end{abstract}

Kata kunci: adsorpsi, biosorben, limbah pertanian, limbah perikanan, low-cost

\begin{abstract}
This review article describes the latest developments in the application of the adsorption method in removing dyes in wastewater. This review article provides information on the application of the dye and the handling of waste from industrial activities that use dye and information about the use of agricultural by-product and fishery solid waste as an absorbent of various types of dyes. Processing wastes containing dyes through adsorption using low-cost alternative adsorbents is a field that is currently developing and interested, because it has benefits, namely for the management of liquid waste and the use of organic solid waste.
\end{abstract}

Keywords: adsorption, agricultural by-product, biosorbent, fishery waste, low-cost

\section{PENDAHULUAN}

Konsumsi air dan aplikasi zat warna yang cukup tinggi dalam proses industri seperti industri tekstil, kertas, kertas karton, plastik, pupuk dan cat menghasilkan sejumlah besar limbah cair yang tercemar (Sulyman dkk., 2017). Hal ini disebabkan oleh penanggulangan limbah industri yang tidak tepat dan tanpa proses pengolahan terlebih dahulu sebelum dibuang ke lingkungan. Keberadaan zat warna dalam limbah industri ini sering dalam konsentrasi yang tinggi dan bersifat toksik sehingga sangat berbahaya bagi kesehatan dan lingkungan (Hassaan \& Nemr, 2017; Sharma dkk., 2014).

Molekul pewarna terdiri dari dua komponen utama yaitu kromofor dan auksokrom. Kromofor bertanggung jawab untuk menghasilkan warna sedangkan auksokrom berperan untuk meningkatkan afinitas molekul untuk melekat pada serat dan membuat molekul larut dalam air (Slokar \& Marechal, 1998). Zat warna terdiri dari gabungan zat organik tidak jenuh seperti senyawa hidrokarbon aromatik, fenol dan turunannya, serta senyawa-senyawa hidrokarbon 
yang mengandung satu atau lebih gugus azo ($\mathrm{N}=\mathrm{N}-$ ). Keberadaan zat organik tidak jenuh dan gugus azo dalam struktur zat warna menyebabkan zat warna bersifat sulit didegradasi oleh mikroorganisme sehingga berdampak terhadap kerusakan lingkungan pada organisme air dengan menghalangi sinar matahari, memperlambat aktivitas fotosintesis dan menciptakan kondisi anaerob yang membatasi pertumbuhan biota air (Daniel dkk., 2013). Selain itu banyak pewarna azo dalam kondisi anaerob terurai menjadi amina aromatik yang berpotensi bersifat karsinogenik sehingga berdampak buruk terhadap kesehatan seperti iritasi kulit, kanker dan mutasi pada manusia (Jeyajothi, 2014).

Beberapa metode konvensional digunakan untuk pengolahan limbah zat warna seperti koagulasi, elektrokimia, osmosis balik, filtrasi nano, dan lain-lain (Gupta \& Suhas, 2009) Namun metode konvensional tersebut dinilai kurang efisien dan membutuhkan biaya yang tinggi dalam proses pengolahannya (Sulyman dkk., 2017). Salah satu proses pengolahan limbah zat warna yang efisien dan ekonomis yaitu metode adsorpsi (Sivakumar \& Palanisamy, 2009). Metode ini menggunakan adsorben sebagai penyerap zat warna. Adsorben yang sering digunakan dalam pengolahan limbah zat warna yaitu karbon aktif, namun penggunaan karbon aktif komersil dianggap sebagai proses yang mahal. Sehingga saat ini sedang berkembang upaya untuk produksi adsorben berbiaya rendah yang lebih baik sebagai alternatif dari karbon aktif diantaranya pemanfaatan limbah padat organik yang berasal dari produk samping pertanian dan perikanan.

Adsorben berbiaya rendah mempunyai aplikasi yang luas untuk pengolahan limbah zat warna. Banyak peneliti telah melaporkan pemanfaatan limbah padat pertanian dan perikanan sebagai adsorben berbiaya rendah. Eksplorasi adsorben berbiaya rendah yang berasal dari limbah pertanian dan perikanan memiliki berkontribusi terhadap kelestarian lingkungan, meningkatkan estetika lingkungan dan juga menawarkan manfaat yang menjanjikan untuk tujuan komersial di masa depan. Pada artikel ulasan ini akan dibahas mengenai limbah zat warna serta metode pengolahannya dan pemanfaatan bahan-bahan alami (limbah padat pertanian dan perikanan) sebagai adsorben berbiaya murah yang telah digunakan dalam adsorpsi zat warna.

\section{PEMBAHASAN \\ Limbah Zat Warna}

Zat warna banyak diaplikasikan pada beberapa industri diantaranya dalam industri tekstil, pencetakan kertas, kulit, fotografi warna, dan industri makanan (Sreelatha dkk., 2011). Aplikasi zat warna yang cukup tinggi tentu sebanding dengan jumlah limbah yang dihasilkan dari proses industri tersebut. Produksi zat warna di dunia terutama dari industri tekstil telah meningkat baik dari volume maupun jenisnya. Total dari $30 \%$ zat warna hilang selama proses pencelupan yang tidak efisien sehingga sekitar $10-15 \%$ zat warna dalam limbah dilepaskan ke lingkungan selama proses produksi dan penggunaan tersebut (Nethaji \& Sivasamy, 2011). Tingkat kehilangan zat warna dalam proses produksi yang masuk ke dalam limbah cair untuk sistem aplikasi pewarna serat utama ditunjukkan pada Tabel 1 (Blackburn, 2004).

Tabel 1. Kehilangan zat warna ke limbah untuk sistem pewarna serat yang berbeda

\begin{tabular}{llc}
\hline $\begin{array}{l}\text { Kelas zat } \\
\text { warna }\end{array}$ & Serat & $\begin{array}{l}\text { Masuk ke } \\
\text { limbah }(\%)\end{array}$ \\
\hline Acid & Polyamide & $5-20$ \\
Basic & Acrylic & $0-5$ \\
Direct & Cotton & $5-30$ \\
Disperse & Polyester & $0-10$ \\
Metal-complex & Wool & $2-10$ \\
Reactive & Cotton & $10-50$ \\
Sulfur & Cotton & $10-40$ \\
Vat & Cotton & $5-20$ \\
\hline
\end{tabular}

Keberadaan zat warna dalam perairan mudah dideteksi bahkan oleh mata manusia meski saat dilepaskan ke badan air dalam kosentrasi kecil. Beberapa zat warna dengan konsentrasi kurang dari $1 \mathrm{mg} / \mathrm{L}$ saat berada dalam badan air dapat terlihat dengan jelas sehingga meski dalam konsentrasi kecil dapat mewarnai badan air yang besar. Selain menurunkan estetika lingkungan, keberadaan zat warna di perairan dapat menyebabkan efek buruk terhadap makhluk hidup seperti menghambat proses fotosintesis yang mempengaruhi ekosistem dalam perairan (Gupta dkk., 2010).

Zat warna tekstil umumnya diklasifikasikan sesuai dengan struktur kimianya atau aplikasinya pada serat tekstil dan aplikasi pewarnaan lainnya. Berdasarkan struktur kimianya zat warna tekstil diklasifikasikan menjadi zat warna azo, zat warna nitro, zat warna indigo, zat warna anthraquinone, zat 
warna phthalein, zat warna triphenyl methyl, zat warna nitrasi dan lain-lain. Klasifikasi zat warna tekstil menurut kromofornya disajikan dalam Tabel 2.

Tabel 2. Klasifikasi dan contoh zat warna tekstil menurut kromofor (Benkhaya dkk., 2017)

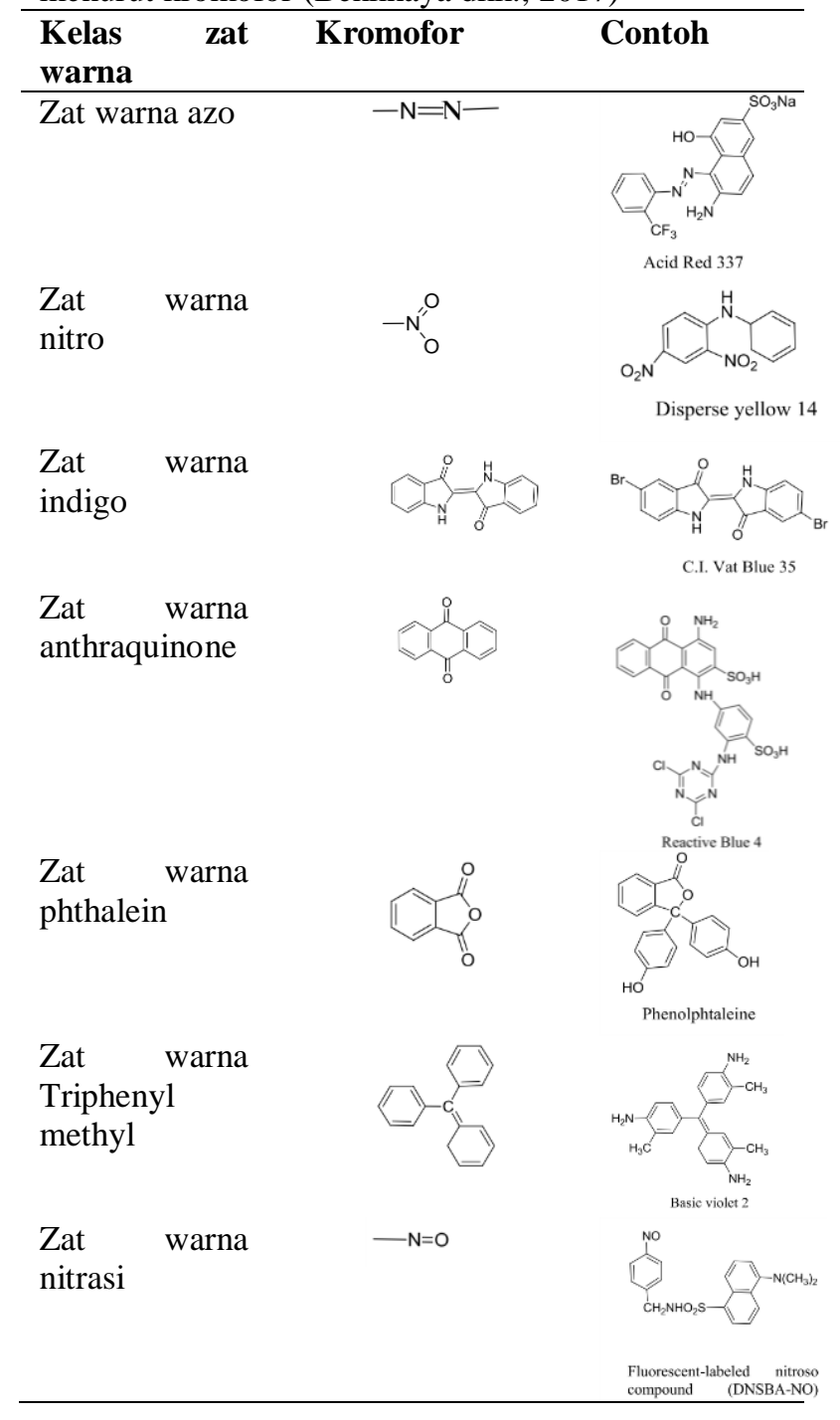

Berdasarkan Tabel 2 dapat dilihat bahwa struktur kimia zat warna terdiri dari gabungan zat organik tidak jenuh seperti senyawa hidrokarbon aromatik, fenol dan turunannya, serta senyawa-senyawa hidrokarbon yang mengandung satu atau lebih gugus azo $(-\mathrm{N}=\mathrm{N}-)$. Karena struktur kimia tersebut menyebabkan zat warna tahan terhadap paparan cahaya, air dan banyak bahan kimia sehingga sulit untuk didekolorisasikan setelah dilepaskan ke lingkungan air (Chuah dkk., 2005). Banyak pewarna azo juga sangat beracun bagi ekosistem dan mutagen sehingga memiliki efek akut hingga kronis pada organisme, tergantung pada waktu paparan dan konsentrasi pewarna azo.
Beberapa dampak buruk zat warna terhadap kesehatan diantaranya iritasi kulit, dermatitis kontak, kemosis, lakrimasi, exophthalmos, kebutaan permanen, rhabdomyolysis, nekrosis tubular akut, muntah gastritis, hipertensi, vertigo, edema wajah dan gangguan pernapasan (Hassaan \& Nemr, 2017).

\section{Metode Penanggulangan Limbah Zat Warna}

Perlakuan air limbah tekstil untuk mengurangi/menghilangkan zat warna dan kontaminan organik terlarut untuk memenuhi standar keberadaannya di lingkungan terus menarik minat peneliti dalam memecahkan permasalahan oleh zat warna. Sifat pewarna yang tidak mudah terurai dan kestabilannya terhadap cahaya dan oksidator mempersulit pemilihan metode yang cocok untuk penghilangannya. Beberapa metode yang telah banyak dilakukan diantaranya fotolisis (Zilfa dkk., 2018), elektrokoagulasi, elektrokimia Fenton, elektro-fenton dan peroksi-koagulasi (Ghanbari \& Moradi, 2014), presipitasi kimia dan AOPs (Kutlu dkk., 2006), foto-oksidasi (Deshannavar et al., 2012), oksidasi kimia dengan ozon, atau kombinasi radiasi UV, ozon dan $\mathrm{H}_{2} \mathrm{O}_{2}$ (Sabur dkk., 2015), biodegradasi oleh bakteri (Sharma dkk., 2014) dan lain-lain.

Metode-metode ini menunjukkan ketidakefektivitas atau keuntungan ekonomi secara signifikan karena menggunakan banyak bahan kimia, penggunaan energi listrik yang cukup tinggi, proses yang rumit, biaya pemeliharaan yang tinggi dan menghasilkan limbah baru seperti lumpur yang membutuhkan pembuangan akhir lagi (Sharma dkk., 2014 ; Priya \& Selvan, 2017). Beberapa contoh metode-metode pengolahan limbah beserta kelebihan dan kekurangan dapat dilihat pada Tabel 3 (Chuah dkk., 2005).

Salah satu metode yang saat ini berkembang yaitu metode adsorpsi. Metode ini menggunakan adsorben sebagai penyerap zat-zat pencemar seperti zat warna, ion logam dan polutan lainnya dari limbah cair industri. Metode adsorpsi telah terbukti sebagai salah satu metode yang efektif untuk pengolahan limbah cair yang mengandung zat warna. Adsorpsi dinilai lebih unggul dibandingkan teknik lain untuk penggunaan kembali air limbah setelah proses pengolahan karena fleksibilitas, desain yang sederhana, tidak menghasilkan lumpur, dan biaya yang murah jika adsorben yang digunakan berasal dari bahan murah dan tidak memerlukan langkah perlakuan awal tambahan 
(Priya \& Selvan, 2017 ; Crini \& Badot, 2008 ; Kumar \& Porkodi, 2009).

Tabel 3. Teknologi pengolahan untuk menghilangkan logam dan zat warna yang melibatkan proses fisik dan / atau kimia

\begin{tabular}{|c|c|c|}
\hline $\begin{array}{l}\text { Metode fisika } \\
\text { dan/atau } \\
\text { kimia }\end{array}$ & Kelebihan & Kekurangan \\
\hline Oksidasi & $\begin{array}{l}\text { Proses cepat } \\
\text { untuk } \\
\text { menghilangkan } \\
\text { zat warna }\end{array}$ & $\begin{array}{l}\text { Biaya energi } \\
\text { tinggi dan } \\
\text { menghasilkan } \\
\text { produk } \\
\text { sampingan }\end{array}$ \\
\hline Ion Exchange & $\begin{array}{l}\text { Penghilangan } \\
\text { yang baik untuk } \\
\text { berbagai logam } \\
\text { berat dan zat } \\
\text { warna }\end{array}$ & $\begin{array}{l}\text { Aborben } \\
\text { membutuhkan } \\
\text { regenerasi atau } \\
\text { pembuangan }\end{array}$ \\
\hline $\begin{array}{l}\text { Teknologi } \\
\text { filtrasi } \\
\text { membrane }\end{array}$ & $\begin{array}{l}\text { Penghilangan } \\
\text { yang baik dari } \\
\text { logam berat dan } \\
\text { zat warna }\end{array}$ & $\begin{array}{l}\text { Menghasilkan } \\
\text { lumpur pekat, } \\
\text { mahal }\end{array}$ \\
\hline $\begin{array}{l}\text { Koagulasi } \\
\text { atau flokulasi }\end{array}$ & Ekonomis & $\begin{array}{l}\text { Menghasilkan } \\
\text { lumpur dalam } \\
\text { jumlah yang } \\
\text { tinggi dan } \\
\text { pembentukan } \\
\text { partikel besar }\end{array}$ \\
\hline $\begin{array}{l}\text { Perlakuan } \\
\text { secara }\end{array}$ & $\begin{array}{l}\text { Proses cepat dan } \\
\text { efektif untuk ion }\end{array}$ & $\begin{array}{l}\text { Biaya energi } \\
\text { tinggi dan }\end{array}$ \\
\hline Elektrokimia & logam tertentu & $\begin{array}{l}\text { pembentukan } \\
\text { produk } \\
\text { sampingan }\end{array}$ \\
\hline Ozonasi & $\begin{array}{l}\text { Diterapkan } \\
\text { dalam kondisi } \\
\text { gas: perubahan } \\
\text { volume }\end{array}$ & $\begin{array}{l}\text { Waktu paruh } \\
\text { singkat }\end{array}$ \\
\hline Fotokimia & $\begin{array}{l}\text { Tidak ada } \\
\text { produksi lumpur }\end{array}$ & $\begin{array}{l}\text { Pembentukan } \\
\text { produk } \\
\text { sampingan }\end{array}$ \\
\hline Iradiasi & $\begin{array}{l}\text { Efektif pada } \\
\text { skala } \\
\text { laboratorium }\end{array}$ & $\begin{array}{l}\text { Membutuhkan } \\
\text { banyak } \quad \mathrm{O}_{2} \\
\text { terlarut }\end{array}$ \\
\hline $\begin{array}{l}\text { Koagulasi } \\
\text { elektrokinetik }\end{array}$ & Ekonomis & \begin{tabular}{lr}
\multicolumn{2}{l}{ Menghasilkan } \\
lumpur & dalam \\
jumlah & yang \\
tinggi &
\end{tabular} \\
\hline Reagen & Dekolourisasi & Menghasilkan \\
\hline Fenton & $\begin{array}{l}\text { efektif untuk zat } \\
\text { warna yang } \\
\text { larut dan tidak } \\
\text { larut }\end{array}$ & lumpur \\
\hline $\begin{array}{l}\text { Perlakuan } \\
\text { secara biologi }\end{array}$ & $\begin{array}{l}\text { Cocok untuk } \\
\text { menghilangkan } \\
\text { beberapa logam } \\
\text { dan pewarna }\end{array}$ & $\begin{array}{l}\text { Teknologi } \\
\text { belum } \\
\text { ditetapkan dan } \\
\text { dikomersialkan }\end{array}$ \\
\hline
\end{tabular}

Penggunaan karbon aktif sebagai adsorben dinilai produktif dalam pengolahan limbah karena luas permukaan spesifiknya yang besar, namun memiliki harga yang mahal sehingga saat ini para peneliti terdorong untuk mengembangkan adsorben alternatif dengan biaya yang murah (Priya \& Selvan, 2017).

Metode adsorpsi dengan menggunakan adsorben yang berasal dari bahan alami dikenal dengan istilah biosorpsi. Proses ini melibatkan fase padat (biosorben, adsorben, bahan alami) dan fase cair (pelarut) yang mengandung spesies terlarut untuk diserap atau adsorbat seperti zat warna dan logam. Biosorpsi merupakan proses fisiko-kimia yang terjadi secara alami dalam biomassa tertentu. Proses yang terjadi memungkinkannya untuk berkonsentrasi secara pasif dan mengikat kontaminan ke dalam struktur seluler biomassa tersebut (Sharma dkk., 2014). Keuntungan metode biosorpsi yaitu teknologi alternatif yang ramah lingkungan dan berbiaya murah karena menggunakan bahanbahan alami yang berasal dari limbah pertanian dan limbah perikanan.

\section{Teknik Preparasi Biosorben}

Salah satu faktor yang mempengaruhi proses adsorpsi yaitu luas permukaan. Semakin luas permukaan biosorben maka semakin besar pula daya adsorpsinya sehingga efektivitas biosorben dalam penyisihan polutan meningkat. Perlakuan awal terhadap biosorben seringkali dilakukan untuk meningkatkan luas permukaan biosorben.

Preparasi dan pembuatan biosorben dari bahan alami merupakan prosedur yang cukup sederhana. Biosorben dapat digunakan secara langsung tanpa proses lebih lanjut. Juga dapat melalui beberapa tahap modifikasi untuk meningkatkan reaktifitas dari gugus-gugus fungsi yang terkandung di dalamnya.

Secara umum, pembuatan biosorben dilakukan melalui beberapa tahap preparasi. Tahap pertama pencucian bahan baku dengan air. Air yang umumnya digunakan diantaranya air keran, air deionisasi (Alseddig dkk., 2017), air destilat (Isiuku, 2017), double-distilled water (Siddiqui, 2018) dan juga kombinasi dari 2 atau lebih jenis air yang berbeda untuk beberapa kali pencucian (Fabbricino \& Pontoni, 2016). Pencucian bertujuan untuk menghilangkan debu, kotoran, partikel, dan senyawa-senyawa pengotor lainnya yang menempel pada permukaan biosorben. 
Setelah tahap pencucian, bahan baku melalui tahap kedua yaitu adsorben dikeringkan untuk mengurangi kadar air. Kadar air yang tinggi dapat menurunkan daya tahan adsorben terhadap serangan mikroorganisme seperti jamur (Zuhroh dkk., 2016). Berapa penelitian menunjukkan proses yang berbeda dalam tahap pengeringan biosorben seperti pengeringan menggunakan cahaya matahari (Furqoni dkk., 2015), oven dengan suhu tertentu (Dai dkk., 2017), dikering-anginkan pada suhu ruangan (Suyono dkk., 2015) dan pengeringan dengan cahaya matahari yang kemudian dilanjutkan dengan oven untuk menyempurnakan pengeringan sehingga menghasilkan biosorben dengan kadar air yang sangat rendah (Nur dkk., 2017). Sampel yang telah dikering-anginkan kemudian digiling, dihaluskan dan diayak dengan ukuran partikel tertentu. Kemudian dilakukan aktivasi biosorben dengan menggunakan aktivator.

Aktivasi merupakan perlakuan terhadap biosorben yang betujuan untuk meningkatkan luas permukaan, memperbesar volume pori dan menghilangkan zat pengotor dengan cara mengoksidasi molekul-molekul pada permukaan biosorben. Aktivasi biosorben dapat dilakukan secara fisika seperti menggunakan gas $\mathrm{CO}_{2}$ (Bello, 2013) dan pemanasan dengan menggunakan microwave (Sivarajasekar dkk., 2017). Aktivasi dengan cara pemanasan bertujuan untuk menguapkan molekul-molekul air yang terperangkap dalam pori-pori biosorben sehingga luas permukaan spesifik biosorben meningkat.

Aktivasi secara kimia dilakukan dengan menggunakan zat aktivator seperti $\mathrm{HNO}_{3}$ (Zein dkk., 2018), $\mathrm{HCl}$ ( $\mathrm{Hu} \& \mathrm{Gao}, 2018), \mathrm{NaOH}$ dkk., 2018) dan KOH (Gao dkk., 2016). Aktivasi dengan larutan asam paling umum digunakan dan terbukti efektif dalam meningkatkan kapasitas adsorpsi. Aktivasi dengan larutan asam dapat melepaskan pengotor atau ion logam seperti $\mathrm{Ca}^{2+}, \mathrm{K}^{+}$, dan $\mathrm{Mg}^{2+}$ yang menutupi sebagian pori-pori adsorben, sehingga pori-pori adsorben memiliki permukaan yang bersih, luas dan gugus aktif yang terkandung pada adsorben semakin reaktif untuk mengikat zat warna (Purnamawati dkk., 2014). Setelah dilakukan aktivasi adsorben kemudian dikeringkan kembali dan biosorben siap untuk digunakan untuk proses adsorpsi.

\section{Penggunaan Biosorben untuk Zat Warna}

Biomassa secara luas digunakan dalam penghilangan beberapa polutan air seperti zat warna, logam berat, fenol, dan klorofenol yang merupakan kontaminan umum yang ditemukan dalam limbah tekstil, kulit, pengolahan makanan, pencelupan, kosmetik, kertas, dan industri zat warna. Bahan alami yang tersedia dalam jumlah besar atau hasil limbah dari kegiatan pertanian dan perikanan, memiliki potensi sebagai biosorben berbiaya murah. Kelimpahan dan ketersediaan produk samping pertanian dan pertanian menjadikannya sumber bahan baku untuk biosorben. Penggunaan biosorben yang berasal dari limbah padat organik seperti limbah pertanian dan perikanan memiliki keuntungan utama yaitu menambah nilai komoditas dari limbah dan juga meningkatkan estetika lingkungan (Chuah dkk., 2005).

Hasil samping/limbah pertanian biasanya mengandung polisakarida hemiselulosa, selulosa, dan lignin sebagai komponen struktural utama. Sehingga sering disebut sebagai zat lignoselulosa. Struktur zat biokimia ini mengandung sejumlah gugus fungsi seperti gugus hidroksil, metil, dan karbonil. Gugus fungsi tersebut berperan dalam proses penyerapan zat warna dalam air limbah (Sulyman dkk., 2017). Penelitian yang dilakukan oleh Villarreal, dkk (2013) melaporkan bahwa senyawa kalsium yang terkandung dalam kulit kemiri bertanggungjawab dalam proses adsorpsi zat warna anionik khususnya zat warna Acid Blue 74 (AB74). Penelitian yang dilaporkan oleh Zein, dkk (2015) menyatakan bahwa gugus fungsi hidroksil dan karbonil merupakan gugus fungsi utama yang ada pada permukaan biosorben yang terlibat dalam proses biosorpsi zat warna methyl red oleh biji rambutan (Zein dkk., 2015).

Limbah perikanan seperti cangkang kerang lala telah dilaporkan oleh Eljiedi \& Kamari (2016) sebagai biosorben zat warna methyl orange and methylene blue. Hasil penelitian menunjukkan bahwa gugus yang berperan dalam proses penyerapan zat warna methyl orange and methylene blue yaitu gugus karbonat (Alseddig dkk., 2017). Limbah cangkang pensi juga telah dilaporkan sebagai biosorben zat warna metanil yellow. Gugus fungsi yang berperan diantaraya gugus fungsi karboksil, karbonil, amina dan karbonat (Zein dkk., 2018). Beberapa penelitian lain mengenai penggunaan biosorben sebagai penyerap zat warna dapat dilihat pada Tabel 4 . 
Tabel 4. Penggunaan biosorben sebagai penyerap zat warna

\begin{tabular}{|c|c|c|c|}
\hline $\begin{array}{l}\text { Zat } \\
\text { warna }\end{array}$ & Biosorben & $\begin{array}{l}\text { Kapasi- } \\
\text { tas } \\
\text { penyera } \\
\text { pan/pers } \\
\text { en } \\
\text { penghila } \\
\text { ngan }\end{array}$ & Referensi \\
\hline Methyl & Biji & 5,643 & (Zein et al., \\
\hline Red & Rambutan & $\mathrm{mg} / \mathrm{g}$ & 2015) \\
\hline Tatrazine & Biji Sirsak & $\begin{array}{l}23,631 \\
\mathrm{mg} / \mathrm{g}\end{array}$ & $\begin{array}{l}\text { (Fauzia, } \\
\text { Furqani, } \\
\text { Zein, \& } \\
\text { Munaf, } \\
\text { 2015) }\end{array}$ \\
\hline $\begin{array}{l}\text { Rhodamin } \\
\text { B }\end{array}$ & Biji Sirsak & $\begin{array}{l}53,376 \\
\mathrm{mg} / \mathrm{g}\end{array}$ & $\begin{array}{l}\text { (Chaidir } \\
\text { dkk., 2015) }\end{array}$ \\
\hline $\begin{array}{l}\text { Methyl } \\
\text { Orange }\end{array}$ & Biji Durian & $\begin{array}{l}6,352 \\
\mathrm{mg} / \mathrm{g}\end{array}$ & $\begin{array}{l}\text { ( Chaidir } \\
\text { dkk., 2015) }\end{array}$ \\
\hline $\begin{array}{l}\text { Reactive } \\
\text { Orange } 16\end{array}$ & Biji psyllium & $94 \%$ & $\begin{array}{l}\text { (Malakooti } \\
\text { an \& } \\
\text { Heidari, } \\
\text { 2018) }\end{array}$ \\
\hline $\begin{array}{l}\text { Indosol } \\
\text { yellow BG }\end{array}$ & Kulit kacang & $\begin{array}{l}25,9 \\
\mathrm{mg} / \mathrm{g}\end{array}$ & $\begin{array}{l}\text { (Sadaf \& } \\
\text { Bhatti, } \\
\text { 2014) }\end{array}$ \\
\hline $\begin{array}{l}\text { Chrysoidi } \\
\text { ne }\end{array}$ & $\begin{array}{l}\text { Serbuk } \\
\text { gergaji yang } \\
\text { diaktivasi }\end{array}$ & $\begin{array}{l}35,60 \\
\mathrm{mg} / \mathrm{g}\end{array}$ & $\begin{array}{l}\text { (Ashraf } \\
\text { dkk.,2019) }\end{array}$ \\
\hline $\begin{array}{l}\text { Methyl } \\
\text { Blue (MB) } \\
\text { dan } \\
\text { Crystal } \\
\text { Violet } \\
\text { (CV) }\end{array}$ & Inti zaitun & $\begin{array}{l}12.22 \mathrm{~m} \\
\mathrm{~g} / \mathrm{g} \\
(\mathrm{MB}) \\
\text { dan } \\
19,19 \\
\mathrm{mg} / \mathrm{g} \\
(\mathrm{CV})\end{array}$ & $\begin{array}{l}\text { (El-Imache } \\
\& \\
\text { Ouazzani, } \\
2018 \text { ) }\end{array}$ \\
\hline $\begin{array}{l}\text { Methylene } \\
\text { Blue }\end{array}$ & Almond gum & $\begin{array}{l}250 \mathrm{mg} / \\
\mathrm{g}\end{array}$ & $\begin{array}{l}\text { (Bouaziz } \\
\text { dkk., 2015) }\end{array}$ \\
\hline $\begin{array}{l}\text { Reactive } \\
\text { blue } 5 \mathrm{G}\end{array}$ & Tulang Ikan & $\begin{array}{l}241,2 \\
\mathrm{mg} / \mathrm{g}\end{array}$ & $\begin{array}{l}\text { (Ribeiro } \\
\text { dkk., 2015) }\end{array}$ \\
\hline $\begin{array}{l}\text { Tartrazine } \\
\text { dan } \\
\text { Amaranth }\end{array}$ & Biji Pepaya & $\begin{array}{l}51 \mathrm{mg} / \mathrm{g} \\
\text { (Tatrazi } \\
\text { ne) dan } \\
37,4 \\
\mathrm{mg} / \mathrm{g} \\
\text { (Amara } \\
\text { nth) }\end{array}$ & $\begin{array}{l}\text { (Weber } \\
\text { dkk.,2014) }\end{array}$ \\
\hline $\begin{array}{l}\text { Malachite } \\
\text { green }\end{array}$ & $\begin{array}{l}\text { Lignin } \\
\text { murni }\end{array}$ & $\begin{array}{l}31,2 \\
\mathrm{mg} / \mathrm{g}\end{array}$ & $\begin{array}{l}\text { (Lee dkk., } \\
\text { 2019) }\end{array}$ \\
\hline Tartrazine & $\begin{array}{l}\text { Serbuk } \\
\text { Gergaji }\end{array}$ & $\begin{array}{l}4,71 \\
\mathrm{mg} / \mathrm{g}\end{array}$ & $\begin{array}{l}\text { (Sushmita } \\
\& \\
\text { Chattopadh } \\
\text { yaya, 2017) }\end{array}$ \\
\hline $\begin{array}{l}\text { Methyl } \\
\text { Blue }\end{array}$ & $\begin{array}{l}\text { Kulit } \\
\text { kacang } \\
\text { tanah }\end{array}$ & $4 \mathrm{mg} / \mathrm{g}$ & $\begin{array}{l}\text { (Etim, } \\
\text { 2019) }\end{array}$ \\
\hline
\end{tabular}

\begin{tabular}{|c|c|c|c|}
\hline \multirow{3}{*}{$\begin{array}{l}\text { Reactive } \\
\text { Blue } 29\end{array}$} & Kitosan & 87,74 & (Naghizade \\
\hline & Kulit Udang & $\mathrm{mg} / \mathrm{g}$ & h \& \\
\hline & Teluk Persia & & $\begin{array}{l}\text { Ghafouri, } \\
\text { 2017) }\end{array}$ \\
\hline Congo & Siput Laut & 80,49 & (Messaoudi \\
\hline Red & & $\mathrm{mg} / \mathrm{g}$ & dkk., 2016) \\
\hline Acid & Serbuk & 5,85 & (Ratnamala \\
\hline $\begin{array}{l}\text { Yellow } \\
17\end{array}$ & Gergaji & $\mathrm{mg} / \mathrm{g}$ & dkk., 2017) \\
\hline $\begin{array}{l}5 \mathrm{G} \text { blue } \\
\text { reactive }\end{array}$ & $\begin{array}{l}\text { Limbah } \\
\text { sekam padi }\end{array}$ & $\begin{array}{l}3,84 \\
\mathrm{mg} / \mathrm{g}\end{array}$ & $\begin{array}{l}\text { (Laurindo } \\
\text { dkk., 2018) }\end{array}$ \\
\hline Malachite & Kulit biji & 48,78 & (Bashanaini \\
\hline Green & $\begin{array}{l}\text { bidara } \\
\text { mahkota } \\
\text { duri Kristus }\end{array}$ & $\mathrm{mg} / \mathrm{g}$ & , 2019) \\
\hline Crystal & Karbon & 41,15 & (Hu \& Gao, \\
\hline Violet & $\begin{array}{l}\text { aktif dari } \\
\text { Daun Ek }\end{array}$ & $\mathrm{mg} / \mathrm{g}$ & 2018) \\
\hline Crystal & Karbon & 36,63 & (Sulyman \\
\hline Violet & $\begin{array}{l}\text { aktif dari } \\
\text { Daun } \\
\text { Kurma yang } \\
\text { telah mati }\end{array}$ & $\mathrm{mg} / \mathrm{g}$ & dkk.,2016) \\
\hline Basic & Cangkang & $95 \%$ & (Ouahabi \\
\hline $\begin{array}{l}\text { Yellow } \\
28\end{array}$ & Keong & & dkk., 2018) \\
\hline Reactive & Cangkang & 41,85 & (Babuponn \\
\hline Red 35 & telur & $\mathrm{mg} / \mathrm{g}$ & $\begin{array}{l}\text { usami \& } \\
\text { Velmuruga } \\
\text { n, 2017) }\end{array}$ \\
\hline Direct & Tongkol & 28,23 & (Berber- \\
\hline $\begin{array}{l}\text { Yellow } \\
27\end{array}$ & jagung & $\mathrm{mg} / \mathrm{g}$ & $\begin{array}{l}\text { villamar } \\
\text { dkk., 2018) }\end{array}$ \\
\hline Methylen & Cangkang & $93,6 \%$ & (Elwakeel \\
\hline e Blue & $\begin{array}{l}\text { kerang } \\
\text { (Anadara } \\
\text { uropigimela } \\
\text { na) }\end{array}$ & & dkk.,2017) \\
\hline Azure A & $\begin{array}{l}\text { Cangkang } \\
\text { keong }\end{array}$ & $89,6 \%$ & $\begin{array}{l}\text { (Al-da } \\
\text { dkk., 2018) }\end{array}$ \\
\hline Reactive & Tulang ikan & 28.5 & (Niero \\
\hline $\begin{array}{l}\text { Red } 120 \\
\text { (RR120) }\end{array}$ & sarden & $\begin{array}{l}\mathrm{mg} / \mathrm{g} \\
\text { (RR120 }\end{array}$ & dkk., 2019) \\
\hline dan & & ) dan & \\
\hline Turqoise & & 45.9 & \\
\hline Blue 15 & & $\mathrm{mg} / \mathrm{g}$ & \\
\hline (TB15) & & (TB15) & \\
\hline Alizarin & Kulit udang & 14,96 & (Chandra \\
\hline Red & & $\mathrm{mg} / \mathrm{g}$ & dkk., 2019) \\
\hline Reactive & Ampas & 68,7 & (da Silva \\
\hline dye & gandum & $\mathrm{mg} / \mathrm{g}$ & dkk., 2019) \\
\hline
\end{tabular}

Berdasarkan tabel di atas dapat dilihat bahwa jumlah zat warna yang diadsorpsi pada adsorben di atas tidak terlalu tinggi dan beberapa bahkan lebih rendah dari $50 \mathrm{mg} / \mathrm{g}$. Maka, untuk meningkatkan efisiensi dan selektivitas proses adsorpsi, perlu dilakukan pengembangan adsorben yang lebih efektif dan 
lebih murah dengan kapasitas adsorpsi yang lebih tinggi.

\section{KESIMPULAN}

Artikel ulasan ini menyajikan berbagai teknologi yang dapat dilakukan untuk mengolah limbah yang mengandung zat warna. Pada ulasan ini berfokus pada penggunaan metode biosorpsi dimana metode ini menggunakan adsorben yang berasal dari bahan-bahan alami (tumbuhan dan hewan). Berbagai macam biosorben yang berasal dari limbah padat pertanian dan perikanan sebagai adsorben zat warna dalam perairan telah dilaporkan. Limbah padat pertanian dan perikanan yang tersedia secara melimpah dapat digunakan pengganti karbon aktif komersial yang mahal dalam menghilangkan zat warna dari larutan berairnya dengan sehingga metode ini lebih murah dan ramah lingkungan.

\section{DAFTAR RUJUKAN}

Aguayo-Villarreal, I. A., Ramírez-Montoya, L. A., Hernández-Montoya, V., BonillaPetriciolet, A., Montes-Morán, M. A., \& Ramírez-López, E. M. (2013). Sorption mechanism of anionic dyes on pecan nut shells (Carya illinoinensis) using batch and continuous systems. Industrial Crops and Products, $\quad 48$, 89-97. https://doi.org/10.1016/j.indcrop.2013.04.0 09

Al-da, M. A., Al-shemary, R. Q., \& Kareem, E. T. (2018). Study on the Use of Snail Shell as Adsorbent for the Removal of Azure A Dye from Aqueous solution. Journal of International Pharmaceutial Research, 45(December).

Alseddig, A., Eljiedi, A., \& Kamari, A. (2017). Removal of Methyl Orange and Methylene Blue Dyes from Aqueous Solution Using Lala Clam ( Orbicularia orbiculata ) Shell. In Proceedings of the International Conference on Education, Mathematics and Science 2016 (ICEMS2016) in Conjunction with 4th International Postgraduate Conference on Science and Mathematics 2016 (IPCSM2016) (Vol. 40003). https://doi.org/10.1063/1.4983899

Ashraf, M. W., Abulibdeh, N., \& Salam, A. (2019). Adsorption Studies of Textile Dye (Chrysoidine) from Aqueous Solutions Using Activated Sawdust. International Journal of Chemical Engineering, 2019. https://doi.org/10.1155/2019/9728156
Babuponnusami, A., \& Velmurugan, S. (2017). Investigation on adsorption of dye (Reactive Red 35) on Egg shell powder. International Journal of ChemTech Research, 10(1), 565-572.

Bello, O. S. (2013). Adsorptive removal of malachite green with activated carbon prepared from oil palm fruit fibre by $\mathrm{KOH}$ activation and $\mathrm{CO} 2$ gasification. South African Journal of Chemistry, 66, 32-41.

Benkhaya, S., Harfi, S. El, \& Harfi, A. El. (2017). Classifications, properties and applications of textile dyes: A review. Applied Journal of Environmental Engineering Science, 3(3), 311-320.

Berber-villamar, N. K., Rosa, A., Moralesbarrera, L., Flores-ortiz, M., Cristianiurbina, E., \& Cha, G. M. (2018). Corncob as an effective, eco-friendly, and economic biosorbent for removing the azo dye Direct Yellow 27 from aqueous solutions. Plos One, 1-30.

Blackburn, R. S. (2004). Natural Polysaccharides and Their Interactions with Dye Molecules: Applications in Effluent Treatment. Environ. Sci. Technol., 38(18), 4905-4909.

Bouaziz, F., Koubaa, M., Kallel, F., Chaari, F., Driss, D., Ghorbel, R. E., \& Chaabouni, S. E. (2015). Efficiency of almond gum as a low-cost adsorbent for methylene blue dye removal from aqueous solutions. Industrial Crops and Products, 74, 903-911. https://doi.org/10.1016/j.indcrop.2015.06.0 07

Chaidir, Z., Furqani, F., Zein, R., \& Munaf, E. (2015). Utilization of Annona muricata L . seeds as potential adsorbents for the removal of rhodamine $\mathrm{B}$ from aqueous solution. Journal of Chemical and Pharmaceutical Research, 7(4), 879-888.

Chaidir, Z., Zein, R., Sagita, D. T., \& Munaf, E. (2015). Bioremoval of methyl orange dye using durian fruit ( Durio zibethinus ) Murr seeds as biosorbent. Journal of Chemical and Pharmaceutical Research, 7(1), 589599.

Chandra, P. P., Visakoti, V., \& Naidu, D. A. (2019). Studies on Biosorption of Alizarin Red dye using Prawn Shell Waste Powder. International Research Journal of Engineering and Technology (IRJET), $6(2)$.

Chuah, T. G., Jumasiah, A., Azni, I., Katayon, S., \& Thomas Choong, S. Y. (2005). Rice 
husk as a potentially low-cost biosorbent for heavy metal and dye removal: An overview. Desalination, 175(3), 305-316. https://doi.org/10.1016/j.desal.2004.10.014

Crini, G., \& Badot, P. (2008). Application of chitosan, a natural aminopolysaccharide , for dye removal from aqueous solutions by adsorption processes using batch studies: A Application of chitosan, a natural aminopolysaccharide, for dye removal from aqueous solutions by adsorption. Progress in Polymer Science, 33, 399-447.

da Silva, B. C., Zanutto, A., \& Pietrobelli, J. M. T. A. (2019). Biosorption of reactive yellow dye by malt bagasse. Adsorption Science and Technology, 37(3-4), 236259.

https://doi.org/10.1177/026361741882399 5

Dai, L., Yao, Z., Yang, W., Xia, M., \& Ye, Y. (2017). Crab Shell: A Potential HighEfficiency and Low-Cost Adsorbent for Dye Wastewater. Fresenius Environmental Bulletin, 26(August).

Daniel, M., Luna, G. D., Flores, E. D., Angela, D., Genuino, D., Futalan, C. M., \& Wan, M. (2013). Adsorption of Eriochrome Black T ( EBT ) dye using activated carbon prepared from waste rice hulls Optimization , isotherm and kinetic studies. Journal of the Taiwan Institute of Chemical Engineers, 44(4), 646-653.

Deshannavar, U. B., Murgod, A. A., Golangade, M. S., Koli, P. B., Samyak, B., \& Naik, N. M. (2012). Photo-Oxidation Process Application for Removal of Color from Textile Industry Effluent. Research Journal of Chemical Sciences, 2(10), 7579.

El-Imache, A., \& Ouazzani, K. (2018). The Olive Core, a Promoter Material for the Adsorption of Dyes: Effects on Certain Parameters, Kinetic and Thermodynamic Study. Oriental Journal of Chemistry, 34(6), 2859-2866. https://doi.org/10.13005/ojc/340624

Elwakeel, K. Z., Elgarahy, A. M., \& Mohammad, S. H. (2017). Use of beach bivalve shells located at Port Said coast (Egypt) as a green approach for methylene blue removal. Journal of Environmental Chemical Engineering, 5(1), 578-587. https://doi.org/10.1016/j.jece.2016.12.032

Etim, E. U. (2019). Removal of Methyl Blue Dye from Aqueous Solution by Adsorption unto Ground Nut Waste. Biomedical Journal of Scientific \& Technical Research, 15(3). https://doi.org/10.26717/bjstr.2019.15.002 701

Fabbricino, M., \& Pontoni, L. (2016). Use of non-treated shrimp-shells for textile dye removal from wastewater. Journal of Environmental Chemical Engineering, 4(4), 4100-4106.

Fauzia, S., Furqani, F., Zein, R., \& Munaf, E. (2015). Adsorption and reaction kinetics of tatrazine by using Annona muricata L seeds. Journal of Chemical and Pharmaceutical Research, 7(1), 573-582.

Furqoni, F., Zein, R., \& Munaf, E. (2015). Biosorption of $\mathrm{Pb}$ ( II ) And $\mathrm{Zn}$ ( II ) from aqueous solutionusing langsat ( Lansium domesticum Corr ) fruit peel. Journal of Chemical and Pharmaceutical Research, 7(1), 546-555.

Gao, Y., Xu, S., Yue, Q., Wu, Y., \& Gao, B. (2016). Chemical preparation of crab shellbased activated carbon with superior adsorption performance for dye removal from wastewater. Journal of the Taiwan Institute of Chemical Engineers, 61, 327335. https://doi.org/10.1016/j.jtice.2015.12.023

Ghanbari, F., \& Moradi, M. (2014). A comparative study of electrocoagulation, electrochemical Fenton, electro-Fenton and peroxi-coagulation for decolorization of real textile wastewater: Electrical energy consumption and biodegradability improvement. Elsevier B.V. https://doi.org/10.1016/j.jece.2014.12.018

Gupta, V. K., Jain, R., Shrivastava, M., \& Nayak, A. (2010). Equilibrium and Thermodynamic Studies on the Adsorption of the Dye Tartrazine onto Waste " Coconut Husks " Carbon and Activated Carbon. Journal of Chemistry \& Engineering Data, 55(11), 5083-5090.

Gupta, V. K., \& Suhas. (2009). Application of low-cost adsorbents for dye removal - A review. Journal of Environmental Management, $\quad 90(8), \quad$ 2313-2342. https://doi.org/10.1016/j.jenvman.2008.11. 017

Hassaan, M. A., \& Nemr, A. El. (2017). Health and Environmental Impacts of Dyes : Mini Review Health and Environmental Impacts of Dyes: Mini Review. American Journal of Environmental Science and Engineering 
2017; $\quad 1(3), \quad 64-67$.

https://doi.org/10.11648/j.ajese.20170103.

11

Hu, Z., \& Gao, Z. (2018). High-surface-area activated red mud for efficient removal of methylene blue from wastewater. Adsorption Science \& Technology, 36(12), $62-79$. https://doi.org/10.1177/026361741668434 8

Isiuku, B. O. (2017). Batch Removal of Metanil Yellow ( MY ) from Aqueous Activated Carbon ( NATPAAC ) from Gmelina aborea ( G . aborea ) Bark: Kinetic and Mechanism Studies. World News of Natural Sciences, 13, 10-26.

Jeyajothi, K. (2014). Removal of dyes from textile wastewater using Orange peel as adsorbent. Journal of Chemical and Pharmaceutical Sciences, (4), 161-163.

Kumar, K. V., \& Porkodi, K. (2009). Equilibrium and thermodynamics of dye removal from aqueous solution by adsorption using rubber wood saw dust. Int. J. Environmental Technology and Management, 10(3/4), 295-307.

Kutlu, S., Solmaz, A., \& Yonar, T. (2006). Colour and COD removal from textile effluent by coagulation and advanced oxidation processes. Coloration Technology, 102-109. https://doi.org/10.1111/j.14784408.2006.00016.x

Laurindo, I., Junior, C., Finger, L., Quitaiski, P. P., \& Neitzke, S. M. (2018). Biosorption of $5 \mathrm{G}$ blue reactive dye using waste rice husk. Eclética Química Journal, 43(3), 45-58. https://doi.org/10.26850/16784618eqj.v43.3.p45-58

Lee, S.-L., Park, J.-H., Kim, S.-H., Kang, S.-W., Cho, J.-S., Jeon, J.-R., ... Seo, D.-C. (2019). Sorption behavior of malachite green onto pristine lignin to evaluate the possibility as a dye adsorbent by lignin. Applied Biological Chemistry, 62(1). https://doi.org/10.1186/s13765-019-0444-2

Malakootian, M., \& Heidari, M. R. (2018). Reactive orange 16 dye adsorption from aqueous solutions by psyllium seed powder as a low-cost biosorbent: kinetic and equilibrium studies. Applied Water Science, $\quad 8(7), \quad 1-9$. https://doi.org/10.1007/s13201-018-0851-2

Messaoudi, E. N., Elkhomri, M., Dbik, A., Bentahar, S., Lacherai, A., \& Bakiz, B.
(2016). Biosorption of Congo red in a fixed-bed column from aqueous solution using jujube shell: Experimental and mathematical modeling. Journal of Environmental Chemical Engineering, 4(4), 3848-3855.

Naghizadeh, A., \& Ghafouri, M. (2017). Synthesis and performance evaluation of chitosan prepared from Persian gulf shrimp shell in removal of reactive blue 29 dye from aqueous solution (Isotherm, thermodynamic and kinetic study). Iranian Journal of Chemistry and Chemical Engineering, 36(3), 25-36.

Nethaji, S., \& Sivasamy, A. (2011). Chemosphere Adsorptive removal of an acid dye by lignocellulosic waste biomass activated carbon: Equilibrium and kinetic studies. Chemosphere, 82(10), 1367-1372. https://doi.org/10.1016/j.chemosphere.201 0.11 .080

Niero, G., Corrêa, A. X. R., Trierweiler, G., Matos, A. J. F., Corrêa, R., Bazani, H. A. G., \& Radetski, C. M. (2019). Using modified fish scale waste from Sardinella brasiliensis as a low-cost adsorbent to remove dyes from textile effluents. Journal of Environmental Science and Health Part A Toxic/Hazardous Substances and Environmental Engineering, O(0), 1-8. https://doi.org/10.1080/10934529.2019.16 31091

Nur, S., Moideen, F., Fadhil, M., Rezania, S., Ponraj, M., Abd, A., ... Komori, D. (2017). Dual phase role of composite adsorbents made from cockleshell and natural zeolite in treating river water. Journal of King Saud University - Science, 6-11.

https://doi.org/10.1016/j.jksus.2017.06.001

Ouahabi, I. E., Slimani, R., Benkaddour, S., Hiyane, H., Rhallabi, N., Cagnon, B., ... Lazar, S. (2018). Adsorption of textile dye from aqueous solution onto a low cost conch shells. Journal of Materials and Environme, 9(7), 1987-1998.

Priya, E. S., \& Selvan, P. S. (2017). Water hyacinth ( Eichhornia crassipes ) - An efficient and economic adsorbent for textile effluent treatment - A review. Arabian Journal of Chemistry, 10, S3548S3558. https://doi.org/10.1016/j.arabjc.2014.03.00 2

Purnamawati, H., Utami, B., Kimia, P., 
Keguruan, F., Maret, U. S., \& A, J. I. S. (2014). Pemanfaatan Limbah Kulit Buah Kakao ( Theobroma cocoa L .) Sebagai Adsorben Zat Warna Rhodamin B. In Prosiding Seminar Nasional Fisika dan Pendidikan Fisika (SNFPF) Ke-5 2014 (Vol. 5, pp. 12-18).

Ratnamala, M., Rahul, M., Sameer, S., Vaani, M., Omkar, \& Devdatt, T. (2017). Column Studies for Removal of Acid Yellow Dye 17 from Synthetic Water Using Activated Saw Dust. Asian Journal of Chemistry, 29(1), 191-195.

Ribeiro, C., Scheufele, F. B., EspinozaQuiñones, F. R., Módenes, A. N., da Silva, M. G. C., Vieira, M. G. A., \& Borba, C. E. (2015). Characterization of Oreochromis niloticus fish scales and assessment of their potential on the adsorption of reactive blue 5G dye. Colloids and Surfaces A: Physicochemical and Engineering Aspects, 482, 693-701. https://doi.org/10.1016/j.colsurfa.2015.05. 057

Sabur, M. A., Khan, A. A., \& Safiullah, A. (2015). Treatment of Textile Wastewater by Coagulation Precipitation Method. Journal of Scientific Research, (January). https://doi.org/10.3329/jsr.v4i3.10777

Sadaf, S., \& Bhatti, H. N. (2014). Batch and fixed bed column studies for the removal of Indosol Yellow BG dye by peanut husk. Journal of the Taiwan Institute of Chemical Engineers, 45(2), 541-553. https://doi.org/10.1016/j.jtice.2013.05.004

Saleh Bashanaini, M. (2019). Removal of Malachite Green Dye from Aqueous Solution by Adsorption Using Modified and Unmodified Local Agriculture Waste. Science Journal of Analytical Chemistry, $7(2)$, 42. https://doi.org/10.11648/j.sjac.20190702.1 2

Sharma, S., Saxena, R., \& Gaur, G. (2014). Study of Removal Techniques for Azo Dyes by Biosorption: A Review. IOSR Journal of Applied Chemistry, 7(10), 6-21. Retrieved from www.iosrjournals.org

Siddiqui, S. H. (2018). The removal of $\mathrm{Cu} 2+$, Ni $2+$ and Methylene Blue ( MB ) from aqueous solution using Lu ff a Actangula Carbon: Kinetics, thermodynamic and isotherm and response methodology. Groundwater for Sustainable Development, 6(December 2017), 141-
149.

https://doi.org/10.1016/j.gsd.2017.12.008

Sivakumar, P., \& Palanisamy, P. N. (2009). Packed bed column studies for the removal of Acid blue 92 and Basic red 29 using non-conventional adsorbent. Indian Journal of Chemical Technology, 16(4), 301-307.

Sivarajasekar, N., Balasubramani, K., Mohanraj, N., Prakash Maran, J., Sivamani, S., Ajmal Koya, P., \& Karthik, V. (2017). Fixed-bed adsorption of atrazine onto microwave irradiated Aegle marmelos Correa fruit shell: Statistical optimization, process design and breakthrough modeling. Journal of Molecular Liquids, 241, 823830. https://doi.org/10.1016/j.molliq.2017.06.06 4

Slokar, Y. M., \& Marechal, A. M. Le. (1998). Methods of Decoloration of Textile Wastewaters. Dyes and Pigment, 37(4), 335-356.

Sreelatha, G., Ageetha, V., Parmar, J., \& Padmaja, P. (2011). Equilibrium and Kinetic Studies on Reactive Dye Adsorption Using Palm Shell Powder (An Agrowaste) and Chitosan. Journal of Chemical Engineering, 56(1), 35-42.

Sulyman, M., Namiesnik, J., \& Gierak, A. (2016). Adsorptive Removal of Aqueous Phase Crystal Violet Dye by Low-Cost Activated Carbon Obtained from Date Palm ( L .) Dead Leaflets. Engineering and Protection of Environment. https://doi.org/10.17512/ios.2016.4.14

Sulyman, M., Namiesnik, J., \& Gierak, A. (2017). Low-cost Adsorbents Derived from Agricultural By-products / Wastes for Enhancing Contaminant Uptakes from Wastewater: A Review. Polish Journal of Environmental Studies, 26(2), 479-510. https://doi.org/10.15244/pjoes/66769

Sushmita, B., \& Chattopadhyaya, M. C. (2017). Adsorption characteristics for the removal of a toxic dye, tartrazine from aqueous solutions by a low cost agricultural byproduct. Arabian Journal of Chemistry, 10, S1629-S1638. Retrieved from http://dx.doi.org/10.1016/j.arabjc.2013.06. 005

Suyono, T., Yuser, M. ., Munaf, E., Aziz, H., Tjong, D. H., \& Zein, R. (2015). Removal of $\mathrm{Pb}$ (II) ions by using Papaya (Carica papaya L ) leaves and Petai (Parkia 
Speciosa Hassk) peels as biosorbent. Journal of Chemical Pharmaceutical Research, 7(9), 100-106.

Weber, C. ., Collazzo, G. ., Mazutti, M. ., Foletto, E. ., \& Dotto, G. . (2014). Removal of hazardous pharmaceutical dyes by adsorption onto papaya seeds. Water Science \& Technology, 70(1), 102-107. https://doi.org/10.2166/wst.2014.200

Zein, R., Astuti, A. W., Wahyuni, D., Furqani, F., \& Munaf, E. (2015). Removal of Methyl Red from Aqueous Solution by Neplhelium lappaceum. Research Journal of Pharmaceutical , Biological and Chemical Sciences, 6(3), 86-97.

Zein, R., Ramadhani, P., Aziz, \& Suhaili, R. (2018). Biosorben cangkang pensi (Corbicula moltkiana) sebagai penyerap zat warna metanil. Jurnal Litbang Industri, 8 (June), 11-16. https://doi.org/10.24960/jli.v8i1.3844.2330
Zilfa, Rahmayeni, Stiadi, Y., \& Adril. (2018). Utilization of Natural Zeolite Clinoptilolite-Ca as a Support of $\mathrm{ZnO}$ Catalyst for Congo-red Degradation and Congo-red Waste Applications with Photolysis. Oriental Journal of Chemistry, 34(2), 887-893.

Zuhroh, N., Prasetya, A., \& Haryani, S. (2016). Adsorpsi Krom(VI) oleh Arang Aktif Serabut Kelapa Serta Imobilisasinya pada Batako. Jurnal MIPA, 39(1), 57-62. 